\title{
MULTIPLEX PCR AND LATEX AGGLUTINATION FOR IDENTIFICATION AND CHARACTERIZATION OF TOXIGENIC CLOSTRIDIUM DIFFICILE FROM RAW MILK
}

\author{
AHLAM A. EL LEBOUDY*; NAGAH M. SAAD ${ }^{* *}$; AMER, A. ${ }^{*}$ and NOHA S. ELMOAZEN. \\ "Department Food Hygiene, Faculty of Veterinary Medicine, Alexandria University, Egypt. \\ *** Department Food Hygiene, Faculty of Veterinary Medicine, Assiut University, Egypt. \\ Email: bosbosadel@yahoo.com
}

\section{ABSTRACT}

Received at: 19/7/2014

Accepted: 19/10/2014
Community-acquired C.Diff. infections have recently been increasing in incidence and severity. Several studies have isolated $C$. Diff. spores from livestock and food suggesting that food may play a role in transmission. The overall goals of this research were to: 1$)$ determine prevalence of $C$. Diff. from raw milk using selective (cycloserine-cefoxitin fructose agar [CCFA]; 2) determine toxigenic profiles of C.Diff. isolated using PCR targeting tpi and $t c d B$ genes. A total of 50 random samples of raw marketable milk were collected from different localities in Assuit city, Egypt. The obtained results indicated that about 11 (22\%) out of 50 examined raw milk samples were positive for C.Diff. using conventional method. While, 2 strains of C.Diff. (18.2\%) out of the positive 11 strains could be detected using the latex agglutination test. The prevelance rate of C.Diff using multiplex PCR was one $(50 \%)$ out of the two tested strains containing the DNA of C.Diff., which was negative for toxin B production. The public health concern of C.Diff and the suggestive measures were disscused. The prescence of toxigenic C.Diff. in raw milk is of great concern and suggests its transmission through milk, which needs proper milking and handling to reduce risk to the public health.

Keywords: Clostridium Difficile, Raw milk, latex agglutination, toxigenic, PCR.

\section{INTRODUCTION}

Milk is one of the few food stuffs consumed in its natural state. It is the only article in the diet, with exception of honey, whose sole function in nature is to serve as a food. It presents a favourable physical environment for the multiplication of contaminating microorganisms. One of these microorganisms, Clostridium difficile.

C. Diff. is a Gram positive spore forming obligatory anaerobic bacillus. Spores can persist in a wide range of aerobic environments $(2,3)$ was first isolated in 1935 from the stool of healthy neonates by Hall and O'Toole (2). It was only in 1978, over 40 years later, that C.Diff. was found to cause human disease in the form of diarrhea and in severe cases pseudomembranous colitis [PMC] $(4,5)$. C.Diff. has been associated with clinical disease in dairy calves $(6,7)$. It has toxigenic characteristics that toxin producing strains of C.Diff. Produce two toxins toxin A, an enterotoxin, and toxin B, a cytotoxin (8). There are four broad categories listed as sources of acquiring $C$. Diff. infection (CDI): environment-toperson, person-to person, animal-to-person and consumption (9)
Mortality rates associated with C.Diff.-related disease in the U.S. increased nearly three-fold from 1999 to 2002. A study, which included C. Diff.-related cases where C.Diff. infection was present but not listed as the underlying cause of death, demonstrated an increase in deaths from 5.7 per million population in 1999 to 23.7 per million in 2004 . It is possible that the increased rates were due to the emergence of a highly virulent strains (10).

Owing to the incrimination of C.Diff. in PMC and littile information about it's occurrence in milk, this study aims to determine the prevelance of C.Diff. from raw milk samples by comparing cultural method by using selective medium (C.Diff. medium), latex agglutination and multiplex PCR. In addition to determination of toxigenic profile of C.Diff. isolated from raw milk using multiplex PCR.

\section{MATERIALS and METHODS}

\section{1- Collection of samples:}

A total of 50 random samples of raw marketable milk were collected from different localities in Assuit city, Egypt. Samples were transferred to the laboratory in clean, dry and sterile containers in an ice box. 
2- Isolation of Clostridium difficile: (11) a- Enrichment of samples:

C. Diff. broth (CDB) which is composed of proteose peptone $(40.0 \mathrm{~g})$, disodium hydrogen phosphate $(5.0 \mathrm{~g})$, potassium dihydrogen phosphate $(1.0 \mathrm{~g})$, magnesium sulphate $(0.1 \mathrm{~g})$, sodium chloride $(2.0 \mathrm{~g})$, fructose $(6.0 \mathrm{~g})$, sodium taurocholate $(0.1)$ was used for enrichment with addition of 2 vials of $\mathrm{Cl}$. difficile supplement (Oxoid, SR96), 7\% defibrinated horse blood (Oxoid SR50) and 2ml tween 80 (12). 3 gram of each sample was added to $10 \mathrm{ml}$ CDB with thorough mixing. Then incubated in an anaerobic cabinet $\left(10 \% \mathrm{CO}_{2}\right.$ and $\left.37^{\circ} \mathrm{C}\right)$ for 7 days (13).

\section{b- Plating: using direct streaking method:}

By streaking a $3 \mathrm{~mm}$ loopful to at least 3 quadrants of the plate which contains C.Diff. agar media (Oxoid CM 0601) added to it $1 \mathrm{gm}$ sodium taurocholate and $2 \mathrm{ml}$ tween 80 that improve the recovery of $C$. Diff. (12) and supplemented with 2 vials C.Diff. selective supplement (Oxoid SR96) and 7\% defibrinated horse blood (Oxoid SR50). Supplement and horse blood added to the media at $50^{\circ} \mathrm{C}$ not higher, which provides extra enrichment allowing for better growth (14). Plates were incubated anaerobically in $37^{\circ} \mathrm{C}$ for 2 days.

\section{3- Identification of C.Diff.:}

a- Characteristic appearance of colonies:

Typical colonies of $C$. Diff. appear as greyish, non hemolytic, swarming colonies (12). With typical odor of horse manure (15). Suspected colonies were subcultured on brain heart infusion agar slopes (BHI) for further identification and toxin detection.

\section{b- Biochemical tests:}

Colonies were identified by biochemical tests that they were tested for indole production and sugar fermentation which includes glucose, lactose and sucrose (16). Acid was produced with gas from glucose. Sucrose was fermented with production of acid only. lactose was not fermented by C.Diff. The pathogen didn't produce indole.

\section{c- Latex Agglutination test:}

The isolated strains of C.Diff. were tested for its antigen. This is an antigen antibody reaction using Oxoid agglutination kits (Oxoid DR1107A, Basingstoke, UK).

\section{d- PCR ribotyping: (17)}

Multiplex PCR for C.Diff. identification and toxigenic type characterization.

\section{1-Primers used:} a-tpi-F(5 '-AAAGAAGCTACTAAGGGTACAAA-3 ') tpi-R(5'-CATAATATTGGGTCTATTCCTAC-3')

b- tcdB-F(5 '-GGAAAAGAGAATGGTTTTATTAA3)

tcdB-R $(5$ -

\section{ATCTTTAGTTATAACTTTGACATCTTT-3')}

\section{2- Procedure:}

a- extraction of DNA by boiling and then centrifugation for $2 \mathrm{~min}$. to settle bacterial debris. b- 10 micron litre of supernatant containing DNA used for subsequent PCR amplification.

c- Thermal cycler conditions.

\begin{tabular}{|c|c|c|c|}
\hline & & & Additional comments \\
\hline $\begin{array}{l}\text { Initial PCR } \\
\text { activation step: }\end{array}$ & $30 \mathrm{sec}$ & $95^{\circ} \mathrm{C}$ & $\begin{array}{l}\text { Hot Star Taq DNA Polymerase is activated by this heating } \\
\text { step. Omniscript and Sensiscript Reverse Transcriptases are } \\
\text { inactivated and the cDNA template is denatured. }\end{array}$ \\
\hline \multicolumn{4}{|l|}{ 3-step cycling } \\
\hline Denaturation: & $0.5-1 \min$ & $94^{\circ} \mathrm{C}$ & \\
\hline Annealing: & $30 \mathrm{sec}$ & $55-65^{\circ} \mathrm{C}$ & $\begin{array}{c}\text { Approximately } 5^{\circ} \mathrm{C} \text { below Tm of primers. Down touch } \\
\text { procedure was implanted, annealing for } 30 \mathrm{sec} \text { at decreasing } \\
\text { temperature during first } 11 \text { cycles. }\end{array}$ \\
\hline Extension: & $30 \mathrm{sec}$ & $72^{\circ} \mathrm{C}$ & $\begin{array}{l}\text { For RT-PCR products of } 1-2 \mathrm{~kb} \text {, increase the extension time } \\
\text { by } 30-60 \mathrm{~s} \text {. For RT-PCR products over } 2 \mathrm{~kb} \text {. }\end{array}$ \\
\hline Number of cycles: & 40 & & $\begin{array}{l}\text { The cycle number is dependent on the amount of template } \\
\text { RNA and the abundance of the target transcript. }\end{array}$ \\
\hline Final extension: & $10 \mathrm{~min}$ & $72^{\circ} \mathrm{C}$ & \\
\hline
\end{tabular}

\section{d- Agarose gel electrophoresis of PCR product:}

Amplified reverse transcriptase-polymerase chain reaction (RT-PCR) products were analyzed by electrophoresis on $1 \%$ agarose gels and stained with ethidium bromide. 


\section{RESULTS}

Table 1: Incidence of C.Diff. in the examined raw milk samples using conventional methods.

\begin{tabular}{cccc}
\hline No. of examined samples & Positive samples & $\%$ \\
\hline 50 & 11 & 22 \\
\hline
\end{tabular}

Table 2: Frequency $\%$ of C.Diff. isolated from raw milk samples using Latex agglutination.

\begin{tabular}{ccc}
\hline No. of examined strains & Positive strains & $\%$ \\
\hline 11 & 2 & 18.2 \\
\hline
\end{tabular}

Table 3: Frequency $\%$ of C.Diff. isolated by using Latex agglutination from raw milk samples using Multiplex PCR.

\begin{tabular}{ccc}
\hline No. of examined strains & positive strains & $\%$ \\
\hline 2 & 1 & 50 \\
\hline
\end{tabular}

Table 4: Frequency \% of C.Diff. toxigenic type (B) isolated by using Latex agglutination from raw milk samples using Multiplex PCR.

\begin{tabular}{ccc}
\hline No. of examined Strains & Positive strains & $\%$ \\
\hline 2 & 0 & 0 \\
\hline
\end{tabular}

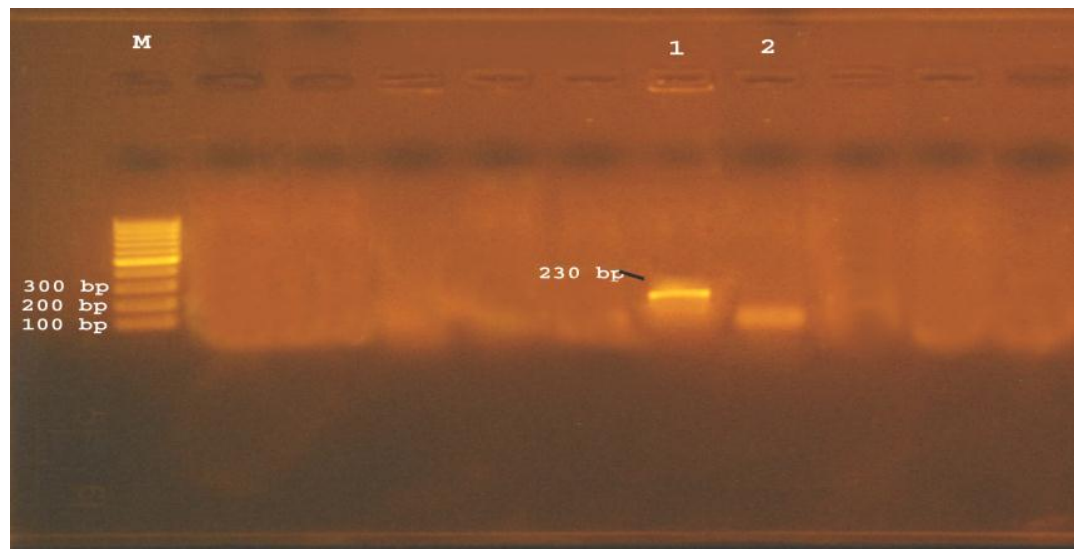

Photo1: Incidence of C.Diff. in the examined raw milk samples using multiplex PCR.

Lane $\mathrm{M}=$ Ladder marker

Lane 1= non toxigenic (B-) C.Diff strain.

Lane $2=$ negative $C$.Diff.

\section{DISCUSSION}

Table 1 showed that $11(22 \%)$ out of 50 examined raw milk samples were positive for C.Diff. using conventional method. While, in Table 2, only 2 strains of C.Diff. (18.2\%) out of the positive 11 samples could be detected using the latex agglutination test. It's clear from the obtained result that latex agglutination test is more accurate for detection of C.Diff than the biochemical reactions. Although latex agglutination test is available for the detection of C.Diff., culture of Clostridium remains essential (15).

Most strains of C.Diff. produce both toxin A and B which cause gastrointestinal disease with severe 
complications such as colonic perforation ,sepsis and death. $(18,19)$.

In the current work, Table 3, cleared that only 1 strain of C.Diff. $(50 \%)$ out of the tested 2 strains containing the DNA of C.Diff. using multiplex PCR, but there was no strain positive to the C.Diff. toxigenic type B (Table 4).

The multiplex PCR-toxigenic culture scheme may be proposed as a reliable diagnostic method, since it provides both strain isolation and toxigenic type characterization within 36 to $48 \mathrm{hrs}$ (17).

Previous studies have reported various prevelance rates of toxigenic C.Diff.0.2 \% in the united states (20).2.5-3\% in the European countries $(21,22)$ and $6.7-9.30 \%$ in Japan $(23,24)$.

Higher results were obtained by (25) that analyzed 132 samples of raw bovine milk for toxigenic C.Diff in western Italy, the organism could be detected from $5(3.8 \%)$ samples of bovine bulk tank milk.

\section{CONCLUSION}

The prescence of toxigenic C.Diff. in raw milk is of great concern and suggests its transmission through milk, which needs proper milking and handling to reduce risk to the public health.

\section{REFERENCES}

Barbut, F.; Lalande, V.; Burghoffer, B.; Thein, H.V. Grimprel, E. and Petit, J.C. (2002): Prevelance and genetic characterization of toxin A variant strains of Clostridium difficile among adults and children with diarrhea in France. J. Clin. Microbiol. 40: 2079-2083.

Bartlett, J.G.; Chang, T.W.; Gurwith, M.; Gorbach, S .L. and Onderdonk, AB. (1978): Antibioticassociated pseudomembranous colitis due to toxin-producing clostridia. N Engl. J. Med.; 298: 531-4.

Brazier, J.S.; Stubbs, S.L. and Duerden, B.I. (1999): Prevelance of toxin A negative /B positive Clostridium difficile strains. J. Hosp. Infect. 42: 248-249.

Clostridium Difficile and Wikipedia. Delme'e, M. (2001): Laboratory diagnosis of C. difficile. Microbiology Unit, Universite' Catholique de Louvain, Brussels, Belgium. the European Society of Clinical Microbiology and Infectious Diseases, CMI, 7, n.8, 411-416.

Hafiz, S. and The Late Oakley, C.L. (1976): Clostridium Difficile: Isolation and characteristics. Department of Microbiology, Medi cal School, University of Leeds, LS2 9NL J. Med. Microbiol.-Vol. 9.
Hall, I.C. and O'Toole, E. (1935): Intestinal flora in newborn infants with a description of a new pathogenic anaerobe, Bacillus difficilis. Am. J. Dis Child; 49: 390-402.

Hammitt, M.C.; Bueschel, D.M.; Keel, M.K.; Glock, R.D.; Cuneo, P.; DeYoung, D.W.; Reggiardo, C.; Trinh, H.T. and Songer, JG. (2008): A possible role for Clostridium difficile in the etiology of calf enteritis. Vet Microbiol. 127(34): 343-352.

Issa, M.; Vijayapal, A. and Graham, M.B. (2007): "Impact of Clostridium difficile on inflammatory bowel disease," Clinical Gastroenterology and Hepatology, vol. 5, no. 3, pp. 345-351.

Jobstl, M.; Heuberger, S.; Indra, A.; Nepf, R.; Kofer, J. and Wagner, M. (2010): Clostridium difficile in raw products of animal origin. Int. J. Food Microbial.138: 172-175.

Kato, H.; Kato, N.and Watanabe, K. (1998): Identific ation of toxin A-negative, toxin Bpositive Clostridium difficile by PCR. J. Clin Microbiol. 36: 2178-82.

Knoop, F.C.; Owens, M. and Crocker, I.C. (1993): Clostridium difficile: Clinical disease and diagnosis. Clin. Microbiol. Rev. 6: 251-265.

Komatsu, M; Kato, H.; Aihara, M.; Shimakawa, K.; Iwasaki, M.; Nagasaki, Y.; Fukuda, S.; Matsuo, S.; Arakawa, Y.; Watanabe, M. and Iwatani, $Y$. (2003): High frequency of antibiotic -associated diarrhea due to toxin Anegative, toxin B-positive Clostridium difficile in a hospital in Japan and risk factors for infection. Eur. J. Clin. Microbiol. Infect. Dis. 22: 525-529.

Larson, H.; Price, A.; Honour, P. and Borriello, S. (1978): Clostridium difficile and the aetiology of pseudomembranous colitis. Lancet 311: 1063-6.

Lemee, L.; Dhalluin, A.; Testelin, S.; Mattrat, M.A.; Maillard, K.; Lemeland, J.F. and Pons, J.L. (2004): Multiplx PCR targeting tpi (Triose Phosphate Isomerase), tcdA (Toxin $\mathrm{A}$ ), and $t c d B$ (Toxin B) Genes for Toxigenic Cultures of Clostridium difficile. Journal of Clinical Microbiology, Dec. P. 5710-5714.

Loo, V.G.; Bourgault, A.M. and Poirier, L. (2011): Host and pathogen factors for Clostridium difficile infection and colonization. N Engl J Med; 365: 1693-1703. CrossRef, PubMed, CAS, Web of Science® Times Cited: 9.

Lyerly, D.m.; Neville, L.M.; Evans, D.T.; Fill, J.; Allen, S.; Greene, W.; Sautter, R.; Hnatuck, P.; Torpey, D.J. and Schawlbe, R. (1998): Multicenter evaluation of the Clostridium difficile TOX A/B TEST. J. Clin. Microbiol. 36: 184-190.

Marler, L.M.; Siders, J.A.; Wolters, L.C.; Pettigrew, Y.; Skitt, B.L. and Allen, S.D. (1992): 
Comparison of five cultural procedures for isolation of Clostridium difficile from stools. J. Clin. Microbiol. 30: 514-516.

Nakamura, S.; Yamakawa, K.; Izumi, J.; Nakashio, S. and Nishida, S. (1985): Germinability and heat resistance of spores of Clostridium difficile strains. Microbiol Immun 29: 113-8.

O'farreli, Sh.; Wilks, M.; Nash, J.Q. and Tabaqchali, S. (1983): A selective enrichment broth for the isolation of Clostridium difficile. Department of Medical Microbiology, St Bartholomew's Hospital, London EC1.

Otten, A.M.; Reid-Smith, R.J.; Fazil, A. and Weese, J.S. (2010): Disease transmission model for community-associated Clostridium difficile infection. Epidemiol Infect 138: 907-14.

Redelings, M.; Sorvillo, F. and Mascola, L. (2007): Increase in Clostridium difficile-related mortality rates, United States, 1999-2004. Emerg. Infect. Dis. 13: 1417-1419.

Rodriguez-Palacios, A.; Staempfli, H.R.; Duffield, T. and Weese, J.S. (2007): Clostridium difficile in retail ground meat, Canada emerg. infect. dis., 13: 485-487.

Romano, $\quad$. (2013): Isolation of toxigenic Clostridium difficile from raw bovine milk and the environment: arisk for public health? Intern. Congress on Bact. and Infect. Dis. Nov. 20-22.

Yaeger, M.; Funk, N. and Hoffman, L. (2002): A survey of agents associated with neonatal diarrhea in Iowa swine including Clostridium difficile and porcine reproductive and respiratory syndrome virus. J. Vet. Diagn Invest 14(4): 281-287.

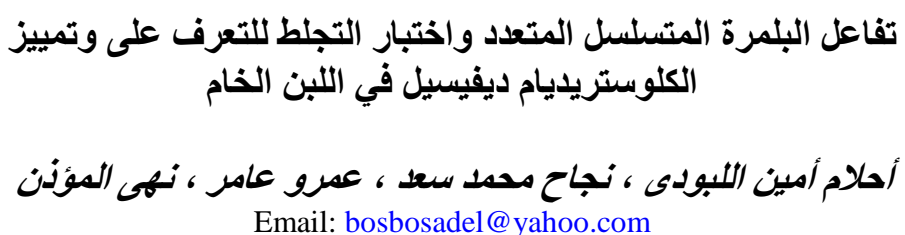

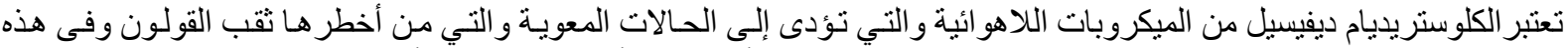

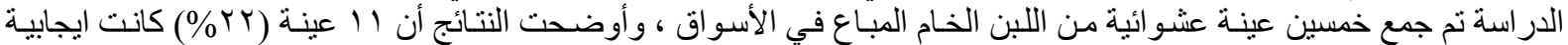

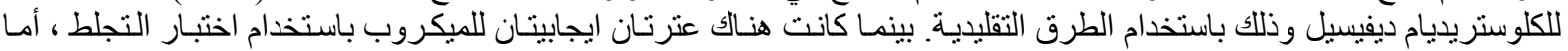

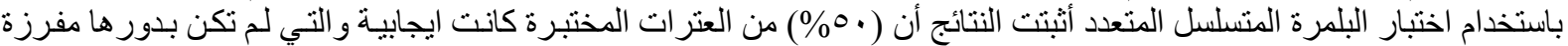

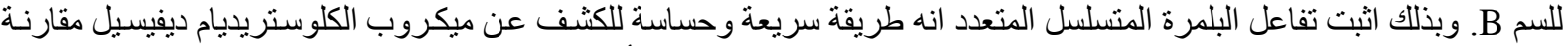
بالطرق التقليدية. هذا وقد تم ذكر الثروط الصحية الو اجب إتباعها لمنع تلوث الألبان بهذا الميكروب. 